\title{
INFLUENTIAL OF ECONOMIC GROWTH, MANPOWER ABSORPTION ON PUBLIC WELFARE
}

\author{
Achmad Daengs \\ Mahjudin \\ University of 45 Surabaya \\ bumigora80@gmail
}

\begin{abstract}
Economic growth is an effort to accelerate the pace of development due to the acceleration of economic growth will be able to push the performance of the sectors there are other more efficient and productive. High economic growth would create a larger distribution of income and improve public welfare. Investment growth plays an important role in economic growth, because investment is a significant component of expenditure that will affect demand and also affect employment opportunities. This study aims to determine the effect of private investment, public investment on economic growth and employment as well as the livelihoods of the urban districts in East Java province. Variables used in this study is composed of exogenous variables private investment and government investment; endogenous variables, namely the welfare of society; intervening variable of economic growth and man power absorption. The data used are time coherent data covering the period 2003-2008 in 38 districts / municipalities in East Java province.
\end{abstract}

Keyword: economic growth, employment, public welfare

\section{INTRODUCE}

Economic growth is one of the efforts to accelerate the pace of development (the engine of growth for development), due to the acceleration of economic growth will be able to push the performance of available other sectors more efficient and productive. The high economic growth will be able to create greater income distribution and increase public welfare. High economic growth coupled with efficient and effective resource allocation can be a stimulus for development, especially in developing countries. In addition, the multiplier effect of greater economic growth in the national development (side prodnets). This will drive the economic sectors in the future economic (Todaro, 2000; 132). Therefore economic growth as the one of the important indicators to analyze the economic development taking place in a country.

Economic growth occurs when (1) people get more resources, or (2) people find many ways of use available resources more efficiently and economic growth is generally defined as an increase in Gross Domestic Product (GDP), the increase in Gross Domestic Product (GDP) can arise through (1) the increase in labor supply, (2) the increase in physical capital or Human Resources (HR), (3) the increase in productivity (sum of products produced by each unit of capital 
or labor) (Case \& Fair: 2004: 325).

High economic growth does not mean much all this time, because these growth was not followed by the increase in jobs opportunity and increased prosperity, poverty reduction and good environment living conditions. Post-crisis rise in per capita income from $\$ 500$ to $\$ 1,500$ (BPS calculation, August 2006) does not show that Indonesia's economy has been able to rise from difficulty to sovereignty. This is seen from the number of poverty and unemployment is growing. In addition, the large-scale exploitation of natural resources to increase GDP cause damage to the natural environment today.

Gross Regional Domestic Product(GRDP) as one of the macro-economic indicators, as well as government spending in various sectors and used for capital investment or investment activity is the first step of production that would affect the level of economic growth. Improving the investment climate conducted by the government through various packages deregulation and de-bureaucratization, simplification licensing mechanisms, softening the terms of investment, as well as the stimulation of investments for sectors in certain areas that are expected the growth in investment are happened both of the public private sector in the country and foreign investors that are expected to increase economic growth and absorb manpower and affect to the income increasing.

Increased economic growth shows the performance of the city development in East Java province at the macro level has risen from crisis situation, while the Gross Domestic Product (GRDP) per capita that shows one measure of the welfare level. Increased Gross Regional Domestic Product (GRDP) per capita has not shown an increase in real purchasing power per capita because of the following:

a. Gross Regional Domestic Product (GRDP) per capita is still not able to detect the gap of mastery asset and receipt of remuneration of production factors, this number just gives guidance about average per capita income in the region.

b. Price increase rates are still in it

c. Population growth rates are also influential.

Bellante (1990) explains, that both in the short term and long-term, the number of required labors are have negative correlation with the wages level. The labor supply provided in an economy are depends on (1) the number of populations, (2) the percentage of people who get into the workforce, and (3) the number of work hours offered by the labors. Furthermore, each of these three components of the amount of labor supplied depends on the market wages. In other words, the applied labor wage is an important factor in determining the demand and supply of labor.

\section{LITERATURE REVIEW}

The complexity of the development occurred causing no one of the proper development theory to be applied to a country. The development theories are dominated by the west economists and continue to experience growth. Since the born of Adam Smith's growth theory, it continues to develop until generate new theories such as the theory of new economic geography and the new growth theory, Kuncoro (2006). The born of the new economic theories above can not be separated from the development of science and the facts that occurred in the economy, which is in line with those expressed by Chalmers (1983) that scientific theories are pulled tightly from the facts of experience gained through observation and experimentation. Furthermore, Gie (1999) stated that the theory is a set of interrelated propositions logically to provide a logical explanation. In line with the meaning of these theories, Tafsir (2004) also suggests that the theory is basically explains the causality. 


\section{Definition of Economic Development}

Mahyudi (2004) states that, development economic is a branch of economics that aims to analyze the problems faced to obtain the ways/ methods of settlement in economic development, especially in developing countries in order to economic development becomes faster and harmony. Meanwhile, Mahyudi (2004) also stated that economic development is economic growth that could lead to the changes of reduced population growth levels and the changes of economic structure, both its roles to the formation of national income, and its roles in preparing the workforce. Furthermore Chenery (in Mahyudi, 2004) stated that, changes in economic structure, especially the changes in substructures industries such as manufacturing, communication, transportation and buildings affect to the subsectors of economy in creating national income, which is influenced by the rate of income per capita and the population of a country.

In UNDP report called Development Report (in Suharto, 2006) states that social development is to encourage economic growth and the economic growth that does not focused on social development will not sustain longer (unsustainable). Sen (in Suharto 2006) proved in his research that the relationship between economic growth and social progress is not automatic, in order to get positive and sustainable then economic growth must be supported by social policies that are the government were pro to developing social. Furthermore, Spicker (1995) states that the provision of social services provided by the state and as certain types of benefits, especially means-tested social security, which means the development of public welfare refers to the provision of social services provided by the state or certain types of benefits, in particular social guarantees which is intended for the poor.
Based on the above it can be said that, development that focused on economic growth, education and health care need to get the government's attention in order to run properly. Meanwhile, for the purpose of development in its implementation may be optimized, it must be integrated with community partnerships through the social policies of the government. Furthermore, to achieve the community welfare then social services that carried out by the government should prioritize to the poor communities.

The difference in the standard of living of a nation or a region, mainly related to the necessities of life, such as clothing, food and housing, has encouraged the emergence of the economists who study the significance of development economics. Herrick and Kindleberger (in Sanusi 2004) states, the economic developments are learn the causes and the way to prevention of mass poverty. Furthermore Jhingan (in Sanusi 2004) states that development economics refers to the various problems of economic development in underdeveloped countries.

Meanwhile, Sanusi (2004) states that development economics using the other principles of economics, both in the original form and after being amended, but not in the most. Development economics is a field of study that is developing the structure of theories and methodologies so quickly. Furthermore, Todaro (in Sanusi 2004) states that, the development economics are much broader than the traditional economics and economical politic, because the development economics associated with the political process and economic activity needed to affect the structural and institutional transformation of the whole level of society.

Based on the above issues, Todaro (in Sanusi, 2004) asking 16 questions about the importance of development economic to be studied are:

1. What exactly is meant by development, how the principles of particular economic theory 
can help the understanding of the development process better.

2. What is the cause of national economic growth and the growth of economy international. Why was there a lot of nations are getting richer while many other nations are still in a poor state.

3. What is the impact of rising world oil prices that are so frequent and fast in the 1970s, especially after a war in the Middle East in October 1973. How is the impact of the economic recession in early 1980s for developing countries that are not the producer/ exporter of petroleum.

4. Why do many developing countries fall into external debt problems that are getting more serious. How are the consequences for the developed countries.

5. Does the rapid population growth in most developing countries will threaten economic growth in developing countries. Does the existence of large families have enough economic reasons in a poor environment and inadequate finance.

6. Why do many people are unemployed in the third world, especially in the cities. Why do so many people continue to immigration, although the opportunities to gain employment in towns are very tiny.

7. What is the development planning and why it should be available. Are the private companies of foreign multinationals should be encouraged to invest in many poor countries. If so what are the terms.

8. What is the impact of foreign aid from the rich countries. Whether developing countries should continue to look for helps, what its terms and what for it will be used. Should the developed countries continue to offering its assistance, what are the terms and what the purposes are.

9. Are the developing countries required to increase the production of primary goods such as agricultural commodities. Should the developing countries trying to develop the industry by building a heavy manufacturing industry as soon as possible.

10. When and with what terms the third world governments must exercise their discretion exchange rate, increase in tariff, and set quotas for imported goods that are considered unimportant for the purpose to fixing chronic balance of payments problems.

11. In terms of development in poor countries, whether they are requires international trade. Who actually enjoy the yield of the trade and how those profits are distributed between nations.

12. Given between $70-80 \%$ of populations in developing countries are live in rural areas, how best to implement the increase in agricultural development in rural areas.

13. How does the effect of recession and unemployment in developed countries on the livelihoods of people in poor countries. Are the poor countries have other way, or only as passive and sensitive spectators to international economic power plays.

14. What will happen the chronic food shortages. If so, which countries would be affected and how to avoid these shortages in the next times.

15. How are the education systems in third world countries can increase economic development or whether the system is only a mechanism that allows a particular group or class of people to defend their wealth, power, and influence.

16. What are underlying the third world countries to form a new international economic system. Is it likely to be happen and when it can be implemented. What may just be the features and how the probable effect on developed countries.

Based on the above it can be said that, development economic are born because of the 
difference in the standard of living that occur between a nation and a region. Level differences may include clothing, housing and food. Furthermore, the discussion of development economics became very widespread, as well as related to human resources, natural resources, the revenues of state and also related to social problems. Noting the scope of economic development, it is no less important in its implementation is the community participations in the implementation of development itself.

\section{Development indicators}

Implementation of development may have a positive or negative impact. To measure the success rate of development it is necessary to have indicators as benchmarks of the success. Kuncoro (2006) states that the development indicators in general consist of: (a) the economic indicators; (b) social indicators.

\section{Economic indicators}

Kuncoro (2006) states that, the development dimension and the focus of development of each region are different from each other, the economic development can be interpreted as economic progress or increase in economic welfare. The increases in real income per capita are only some of the indicators of economic prosperity, because the economic welfare contains the value of the level of income distribution desired. Subsequently, Kuncoro (2006) adds that, which are included economic indicators in development are: (a) GNP (GNI) per capita; (b) the rate of economic growth; (c) GDP per capita.

The World Bank (in Kuncoro, 2006) classifies the performance of the economy of a country with a GNI (Gross National Income) or (Gross National Product) per capita, where GNI is gross national income divided by the total population, then the classification of countries based on level of GNI per capita income include:
1. Low-income countries (low-income economies) are a group of countries with GNI per capita less than $\$ 745$ in 2001

2. The middle-income countries (middle income economies) are a group of countries with a GNI per capita more than $\$ 745$ in 2001 . The group of middle-income countries is further divided into two (2) categories:

a. the low level of middle-income countries (lower middle income economies) with a GNI per capita between $\$ 746$ to $\$ 2,975$

b. the up level of middle-income countries (upper middle income economies) with a GNI per capita of $\$ 2,975$ to $\$ 9,205$

3. The high-income countries (high income economies) are a group of countries with a GNI per capita of US \$9,206 or more in 2001 .

Low or medium-income countries are also known as developing countries. Meanwhile, Todaro (in Kuncoro, 2006: 20) argues that developing countries have the following characteristics: (a) the low level of life; (b) the low level of productivity; (c) the high level of growing population and dependency; (d) the high level of unemployment rate. Furthermore Kuncoro (2006) stated that, based on the classification of the World Bank in 2003 Indonesia classified as low-income countries because it has a GNI per capita of US \$745.

\section{Economic Growth}

Economic growth by McConnell and L.Brue (2002) is the increase in real GDP (Gross Domestic Product) in long-term or an increase in GDP per capita over the long term. While Samuelson and Nordhaus (2005) define economic growth as a potential increase in GDP of a country or an increase in national output.

In Jhingan Kuznets (1988) opinion; Todaro (2000); Rashid (1997: 204) the economic growth as the ability of a country to provide various types of goods and services in the long term. 
Economic growth according to Case (2004) is an increase in the output of an economy or as an increase of real GDP per capita. Furthermore, Taylor (2004) describes an upward trend in real GDP, reflecting expansion economy over time. In other words, economic growth is an increase total output in the economy or an increase of real GDP per capita or the economic growth is an upward trend of real GDP as a result of the development of economic activity in the long term.

Economic growth according Soubbotina and Sheram (2000) in addition to increasing the wealth of a country it is also gives the potential to reduce poverty and address social problems. Meanwhile, according to Scott (1993) economic growth has the meaning are:

a. Growth in total output that is explained by the growth of variety inputs, especially labor and capital. The growth rate are depends on the volume of investment, efficiency, and growth in employment.

b. The growth of these inputs needs to be explained as changes in efficiency in production output.

Definition of economic growth was also expressed by some Indonesian economists such as Djojohadikusomo (1994) that the economic growth associated with the increased production of goods and services in economic activities. In other words, the growth linked to the onedimensional development and with increased production and income yields. Boediono in Kuncoro (2004) states economic growth is the increase in output per capita in the long term. Sukirno (1981) describes the economic growth is the increase in income per capita level that exists in the country from year to year.

Based on some opinions above, it can be concluded that economic growth contains two elements. First, the economic growth related to the increase in the production of goods and services or real income per capita. Second, economic growth is related to time, from year to year or long term.

GDP Economic growth is as a quantitative measure that describes the development of an economy in a given year when compared with the previous year (Sukirno, 2006), or economic growth is defined (Nanga, 2005) as an increase in the ability of an economy to produce goods and services. Economic growth refers to the quantitative change and it is usually measured by using data of Gross Domestic Product (GDP) that is the total market value of final goods and services which produced in an economy over a certain period (usually one year). Or with a Gross National Product (GNP) or gross national product that is the total market value of final goods and services produced by the peoples of a country for a certain period. To calculate the rate of economic growth it can be done by using the following formula:

$\mathrm{g}=\frac{G D P_{1}-G D P_{0}}{G D P_{0}} \times 100 \%$

where:

$\mathrm{g}$ is the rate of economic growth (percentage)

GDP $_{1}$ (Gross Domestic Product) is the real national income that is calculated at a fixed price that is achieved in a year (year 1)

$\mathrm{GDP}_{0}$ is the real national income in the previous year (year 0)

\section{Structure of Manpower Absorption}

A process for the labor production is one of the production factors that have a significant role. Expenditures for labor by manufacturers is one of the primary input components, which include wages and salaries, benefits such as rents, interest, profits both in the form of goods and money. To show the magnitude of required labor amount is by using the coefficient of labor that is a number that indicates the number of the required labor amount to produce one unit of output. 
These coefficient values can be used to detect any change in final demand. When the final demand increases then the end result will increase the amount of labor that can be absorbed.

Population of a country or region can be divided into two groups, which are manpower and non-manpower. Manpower is classified as the population who aged in working age limit in Indonesia at minimum of 15 years, with no maximum age limit. Manpower is broken up into two groups: labor force and non-labor force. The labor force is the manpower or the population of working age who work, or have a job but temporarily was not working, and looking for jobs. While that included non labor force is manpower or the population of working age who are not working, do not have a job and are not looking for work; i.e. those whose activities in school, taking care of the household (not a career woman), receive income but is not a direct payment for services employment (retired). In the context of employment, the population can be separated as shown in Figure 1:

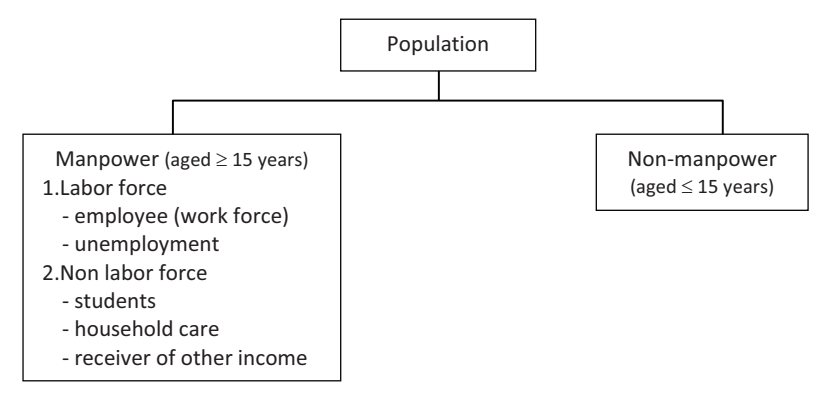

Source: Dumairy, 1996

Figure 1.

\section{Separating of Population Based on Work Force Approach}

Population is a source of labor force that required in development despite its passive role following the economy developments, if the economy is unable to provide employment opportunities for the labor force, there will be unemployment and then become the economy burden and will further reduce per capita income. One of the causes of unemployment is due to the demand for labor in the formal sector has not increased much. According to Edgar O.Edwards in Arsyad (2004) there are five forms of unemployment that are:

1. Open unemployment: either voluntary (those who will not work because it expects a better job) or involuntary (those who want to work but do not get a job).

2. Semi unemployed (under employment) i.e. those who work duration (days, weeks, seasonal) less than they can do.

3. Seemed to work but does not work fully: those who do not classified as the open unemployed and underemployed, included here are:

a) Disguised unemployment, for example, the farmers who work in the field full day when it actually does not take as long as a full day.

b) Hidden unemployment, for example, people who work but not in accordance with the level or type of their education.

c) Early pension.

4. Weak labor (impaired): i.e. those who may work full time, but the intensity is weak because of malnutrition or diseased.

5. Unproductive labor; i.e. they are able to work productively, but because inadequate helper resources, then they can not produce anything well.

\section{Theory of Modern Growth}

Theory of modern growth among others proposed by the experts as follows:

\section{Growth Theory of F Roy Harrod and Evsey D. Domar}

Theory of Harrod and Domar (Todaro, 2004) essentially analyze the following issues: what conditions or how circumstances that should be created in the economy to ensure that over the years the ability to produce ever-increasing as a result of investment in the previous year that will always be fully usable (Sukirno 2006:256). In this 
theory, the capital formation is seen as an expense that would add to the ability of an economy to produce goods, as well as expenditure will increase effective demand of a society. Harrod's attention was focused on the requirements that must be met to maintain a balance between saving, investment, and income in the dynamics of economic growth. Conclusions that expressed by Harrod is that in the growth process there was inherently instability factor (instability theorem) that need undertaking in order to maintain growth based on stable balance.

While Evsey D. Domar attention was focused on: first, the effect of investment to increase aggregate demand at this time, and second, and the influence of investment to increase production capacity. If the real capacity real is still below the installed capacity, it will reduce investment in the future, so that the unemployed capital is become redundant and make the economy into a depression, but if the increased investment in the right dose, the aggregate demand will increase in an sufficient amount to absorb all new production capacity (Todaro, 2004).

But eventually both of focuses are end at the same conclusion that is the importance of investing in the process of economic growth. Investment has two properties: (a) creating revenue; (b) expanding the production capacity of the economy by increasing the capital stock. Investment can create income for their investment deals. Therefore, as long as the investment remains ongoing, real income and output will continue to grow. Nevertheless for the balance going to the "full employment", both income and output speed must be equal to the speed of the increase in production capacity. If otherwise there will be excess capacity. When this is happens in the economy that is declining revenues and employment in the next period and the growth becomes clocked or unsteady.

If the "full employment" will be maintained in the long term, then investment must always be enlarged, so that investment is always great, the real income growth constantly at a level sufficient to ensure a level of capacity utilization in full on the growing capital stock. The required income growth rate is called the warranted rate of growth (the required growth rate). Theory of Harrod-Domar using the following assumptions:

a) The economy in full employment

b) The economy in two sectors, household sector and corporate sector.

c) The amount of public savings is proportional to the magnitude of national income.

d) The desire to save is remains.

e) Capital output ratio is remains.

\section{RESEARCH METHOD}

This research included in the type of explanation study and confirmatory study or hypothesis testing study. This means that the research is intended to explain the influence between variables or causal relationships between variables through hypothesis testing (Singarimbun and Efendi, 1995).

The data used in this study is a combination of secondary data in the form of time series data and cross data so-called panel data. Time series data covering the period 2003-2008, while the cross data over the whole district or city in East Java Province.

\section{Population, Sample and Sampling Techniques}

Based on the opinions expressed by Indriantoro and Supomo (2002), then in this study, the unit of analysis is the district or city located in East Java Province. Furthermore, whole of district or city located in the area of East Java Province also called the population.

Furthermore, because the population was limited and the member population are relatively small of 38 district or city, then in this study using census method. Census is a study of all members of the population (Indriantoro and Supomo, 2002). 


\section{Operational Definition of Variables}

The operational definition of each variable studied, that are:

a. Economic growth (X), is defined as economic growth each year and in each District / City of East Java Province (percent).

b. Manpower absorption (Y), defined as the number of working-age population that working in various economy sectors every year and in each District / City of East Java Province (people).

c. Public welfare $(Z)$, defined as the fulfillment of economic and social needs of people on every District / City of East Java Province. Welfare values are a proxy for the value composite of Human Development Index (HDI).

\section{Data Analysis Technique}

Path analysis is a technique for analyzing the causal relationships that occur in multiple regressions if the independent variables affect dependent variable not only directly but also indirectly (Ghozali, 2009).

Path analysis is the development of a regression analysis. In the regression analysis attempts tostudy therelationshipbetween variables was never questioning why the relationship exists or not. Besides never questioned whether the existing relationship between the dependent variable (Y) and the independent variable $(\mathrm{X})$ is caused by the variable $\mathrm{X}$ its own or other variables between the two variables are so variable $\mathrm{X}$ does not directly affect the variable $\mathrm{Y}$ but there are other variables as intermediate variables.

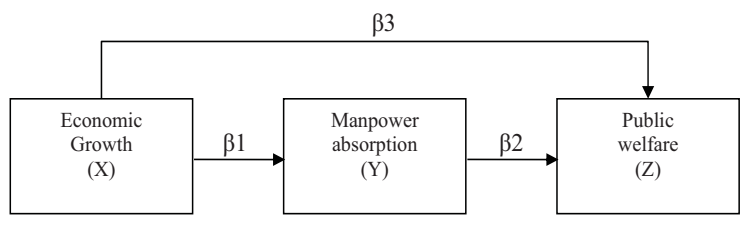

Figure 2. Conceptual Framework
Path analysis equation:

$$
\begin{aligned}
& Y=b 1 X ; \quad Y=0,2532 X \\
& Z=b 2 Y+b 3 ; Z=0,325 X-0,3601 Y
\end{aligned}
$$

Table 1.

\section{Coefficient of Path Analysis on Direct and} Indirect Effect

\begin{tabular}{|l|c|c|c|}
\hline \multicolumn{1}{|c|}{ Results Path Analysis } & Path coefficient & Prob & Description \\
\hline Economic growth $\rightarrow$ public welfare & 0.2532 & 0.000 & Significant \\
\hline $\begin{array}{l}\text { Manpower absorption } \rightarrow \text { public } \\
\text { welfare }\end{array}$ & -0.3601 & 0.000 & Significant \\
\hline
\end{tabular}

Source: Data processed

According to the table 1 above it can be explained as follows:

1. The value of path coefficients for the variables of economic growth on public welfare is positive for 0.2532 has significant influence in the same direction, it is meaning that when economic growth is increasing it will improve the public welfare in District or City in East Java province, and vice versa when economic growth declines it will decreasing the public welfare in the District or City in East Java Province.

2. The value of path coefficient for the variable of manpower absorption on public welfare has negative influence of -0.3601 in opposite directions, it is meaning that the increase in manpower absorption does not necessarily provide increased public welfare in the District of City in East Java province, and vice versa decreased manpower absorption does not always leave declines in public welfare.

Hypothesis 1 stated economic growth has effect on the public welfare in District or City in East Java province. Hypothesis test results can be seen in Table 1, the value of the path coefficient of 0.2532 and the probability value of $0.000<$ significance level (a) 0.05 , indicating that the economic growth have a significant influence on the public welfare. So the first hypothesis $\left(\mathrm{H}_{1}\right)$ who stated economic growth has effect on public welfare in the district of city of East Java Province was received. 
Hypothesis 2 stated manpower absorption ahs effect on the public welfare in the District or City in East Java province. Hypothesis test results can be seen in Table 1, the value of the path coefficient of 0.3601 and the probability value of $0.000<$ significance level (a) 0.05 , indicating that the manpower absorption have a significant influence on the public welfare. So the second hypothesis $\left(\mathrm{H}_{2}\right)$ which states that manpower absorption has effect on public welfare in the district or city in East Java Province was received.

\section{Effect of Economic Growth on Public Welfare}

Based on the results of path analysis Table 1 shows that the path coefficient of 0.2532 and probability value of 0.000 is smaller than the significance level (a) of 0.05 , which means that economic growth have effect to the public welfare in the District/City in East Java province, these conditions occur that the increasing of economic growth was encourage the public welfare.

The results support previous research conducted by Barro (1991), Brata (2004, 2005), Djoko Mursinto (2004). Brata research results (2004, 2005) states that the expenditure per capita has significant effect on life expectancy. There are the reciprocal relationships between economic performances in human development. Joko Mursinto research results (2004) reported that region revenue (PAD) have contribution to total regional revenue (TPD) up to $32.66 \%$.

The results support the theory of optimum Pareto stated by Wilfledo Pareto showed that economic growth can be used to improve the public welfare collectively consisting of individuals in society. This concept states that if at least one person to be better and no one become worse off then the public welfare was increases.

To support the results of a study that economic growth will affect to the public welfare based on table 1 shows an increase in economic growth in the city of Surabaya in 2004-2005 amounted to $7.35 \%$ and from 2007 to 2008 which contribute to the improvement of public welfare of $88.23 \%$. Malang in 2005-2007 of 6.10\% indicates an increase in economic growth contributed to the improvement of public welfare. So that happened in Pasuruan in 2004-2005 showed an increase in economic growth of $6.15 \%$, in Surabaya in 2007 2008 amounted to $6.74 \%$ which contribute to the improvement of public welfare.

Suparmoko (2002: 434) says that economic growth as measured by the development of the production of goods and services or national income, is necessary because there are two factors that determine that are the increasing population from year to year and the increasing level of public welfare as a result of the development itself. Economy has a duty to give a rational principle for business as these economic activity is not only reaching out to the needs of individual financial life and short-term, but provide a surplus for the welfare of many people in the country. This is supported by empirical data presented in Tabel 1 that in the Surabaya and Pasuruan show an increase in economic growth in 2004-2005 and 2007-2008 that contribute to the improvement of public welfare.

Todaro (in Arsyad, 2005: 5) states that the success of economic development is indicated by the three principal, these are: (1) the development of public ability to meet basic needs; (2) the rise in self-esteem as financial; (3) increasing the ability of people to choose. Arsyad (2005:6) states that economic developments are: (1) the process which means that it changes continuously; (2) the efforts to raise per capita income; (3) the increase in the per capita income should continue; (4) improvement of institutional system both institutional and regulatory. The success of development as an example in the three cities of Surabaya, Malang and Pasuruan shown by an increase in economic growth (Table 1) starting in 2003-2008 that contributed to the development of the ability of people to meet their basic needs, that is improving the public welfare. 
The findings of this study do not contradict to the Neo-Classical welfare theory explains that the welfare associated with the utility or satisfaction of consumption or function of various goods and services. Based on the above, the economic growth affect the level of welfare does not contradict to the Neo-Classical welfare theory. Therefore, based on the analysis of the results of this study, the theoretical findings generated that are economic growth have positive and significant effect on the welfare.

Based on these descriptions, it can be said that economic growth directly affects the public welfare in East Java. The higher the economic growth it will directly be able to absorb a lot of manpower that eventually will improve the public welfare.

\section{Effect of Manpower Absorption on Public Welfare}

Based on the results of path analysis Table 1 shows that the path coefficient value of 0.3601 and probability value of 0.000 is smaller than the significance level (a) of 0.05 , it is meaning that the manpower absorption has effect on public welfare in District/City in East Java Province. The results of this study support previous research conducted by Kim (1997); Buffes (1998); Dessus (2000), Darussalam (2005).

Kim (1997) suggests that the manpower has effect on economic growth in South Korea. Likewise Dessus (2000) states that the greater and varied economic activities in a society, of course it is good because it will create jobs. Employment will give someone's income and his family to meet life needs, especially the basic needs: food, clothing, housing, health and education. Darussalam (2005) states the land use has impact on manpower absorption and the establishment of sectoral value added and public welfare in Batam Island.

To support the results of studies that the manpower absorption has effect on the public welfare are based on table 1 that shows an increase in manpower absorption in Surabaya in the year 2004 to 2005 by $2 \%$ and 2008 at $0.31 \%$, which contributed to the improvement of public welfare. Malang in 2005 amounted to $3.98 \%$ and by $1.64 \%$ in 2008 showed an increase in manpower absorption contributed to the improvement of public welfare. So that happened in Pasuruan in 2004-2005 at 0.50\% showed an increase in manpower absorption and in Surabaya in 20072008 amounted to $5.34 \%$, which contributed to the increase of $3.98 \%$ manpower absorption that contribute to the improvement of public welfare. Pasuruan in $2004-2005$ by $0.50 \%$ and $3.98 \%$ in 2008 showed an increase in manpower absorption that contributes to the improvement of public welfare.

\section{CONCLUSION}

Economic growth has significant effect on public welfare

The increase of goods and services production will need manpower so as to improve the public welfare. Economic growth, as measured by the development of the production of goods and services or national income, is necessary because there are two factors that greatly determine i.e. the increasing of population from year to year and the increasing level of public welfare as a result of the development itself.

Manpower absorption has significant effect on public welfare

One of the main goals of development is the creation of greater employment opportunities and adequate quality to be able to absorb the additional labor force entering the labor market in every year. Job opportunities will provide income, and by the income each person and their families can meet their needs, especially basic needs such as food, clothing, housing and health and education, all of which it certainly will improve the public welfare itself. 


\section{REFERENCES}

Baffes, John and Anwar Shah, 1998. Productivity of Public Spending, Sectoral Allocation Choice, and Economic Growth, Economic Development and Culture Change, Vo. 46, No. 2: pp. 291-330.

Barro, Robert J and Xavier Sala-I-Martin, 1991. Economic Growth in A Cross Section of Countries, the Quarterly Journal of Economics, Vol. 106 : pp. 407-443.

Bellante, C and Mark Jackson, 1990. Ekonomi Ketenaga Kerjaan, Jakarta: LPFEUniversitas Indonesia.

Brata, Aloysius Gunadi, 2004. Analisis Hubungan Imbal Balik Antara Pembangunan Manusia dan Kinerja Ekonomi Daerah Tingkat II di Indonesia. Yogyakarta: Lembaga Penelitian Universitas Atmajaya. Halaman 1-10. , 2005. Investasi Sektor Publik Lokal, Pembangunan Manusia, dan Kemiskinan. Yogyakarta: Lembaga Penelitian Universitas Atmajaya, Halaman 1-19.

Case, E Karl and Ray C.Farir, 2004. EPrinciples of economic. New Jersey: Pearson Prentice Hall.

Darussalam. Wan, 2005. Pengaruh Peruntukan Lahan Terhadap Penyerapan Tenaga Kerja Dan Pembentukan Nilai Tambah Sektoral Serta Kesejahteraan Sosial Masyarakat Pulau Batam. Surabaya: Disertasi, Program Pascasarjana Universitas Airlangga,

Dessus, Sebastian and Remy Herrera, 2000. Public Capital and Growth Revisied: A Panel Data Assessment, Economic Development and Cultute Change, Vol.102: pp. 407-419.

Djojohadikusumo, Sumitro, 1994. Dasar Teori Ekonomi Pertumbuhan dan Pembangunan. Jakarta: LP3S.
Ghozali, H, Imam, 2009, Statistik Multivariate dengan SPSS, Badan Penerbit Universitas Diponegoro, Semarang.

Hakim, Abdul, 2000"Ekonomi Pembangunan", ekonisia, Yogyakarta.

Indrianto, Nur dan Bambang Supomo, 2002, Metodologi Penelitian Bisnis untuk Akuntansi dan Manajemen, Yogyakarta, BPFE.

Jhingan M.L, 1988. Ekonomi Pembangunan dan Perencanaan. Jakarta: Rajawali.

Kadiman, Irawan. 2003. Teori dan Indikator Pembangunan. Lembaga Administrasi Negara. Jakarta

Kim, Sung Tai, 1997. The Role of Local Public Sector in Regional Economic Growth in Korea. A sian Economic Journal, Vol. 11, No.21: pp. 155-168.

Kuncoro, Mudrajad. 2006. Ekonomika Pembangunan. STIM YPKN. Yogyakarta. Gie.T.L. 1999. Pengantar Filsafat Ilmu. Liberty. Jakarta.

Kuncoro, Mudrajat, 1997.Ekonomi Pembangunan (Teori, Masalah, dan Kebijakan). Yogyakarta: Akademi Manajemen Perusahaan YKPN.

Lincoln Arsyad, 2004, Pengantar Perencanaan dan Pembangunan Ekonomi Daerah, Yogyakarta, BPFE-UGM.

Mahyudi. 2004. Ekonomi Pembangunan dan Analisis Data Empirik. Ghalia Indonesia. Bogor.

McConnel, R Campbell and Stanley L Brue, 2002. Economics. New York: McGrawHill Companies.

Mursinto, Djoko, 2004. Pengaruh Derajat Desentralisasi dan Tingkat Kemandirian Keuangan Daerah Serta Elastisitas Pendapatan Asli Daerah Terhadap Kategori Pemerintahan Kabupaten dan Kota Pada Awal Otonomi Daerah di Propinsi Jawa Timur, Disertasi, Surabaya: PPS-Universitas Airlangga. 
Nanga.Muana, 2005, "Makro Ekonomi, Teori, Masalah dan Kebijakan", PT Raja Grafindo Persada, Jakata.

Nasikun, 2007. Sistem Sosial Indonesia. Rajagrafindo Persada. Jakarta.

Rasyid, Ryass, 1997. Pengembangan Aparatur Pemerintah Daerah dalam Menyongsong Era Otonomi Daerah. Jurnal Studi Indonesia, Vol. 7, No. I. Halaman 18-28.

Samuelson, Paul A and William D.Nordhaus, 2005. Economics. New York: McGrawHill Companies.

Sanusi, Bachrawi. 2004. Pengantar Ekonomi Pembangunan. Rineka Cipta. Jakarta.

Scott, Maurice FG, 1993. Explaining Economic Growth. AEA Proper and Proceding, Vol. 83, No. 2, May: pp. 421-425.

Spicker, Paul. 1995. Social Policy. Themes and Approaches. Prentice-Hill. London.
Subbotina, Tatyana P. with Katherine A. Sheram, 2000. Beyoned Economic Growth, Meeting the Challenger of Global Development. Washington, D.C: The World Bank,

Suharto, Edi. 2006. Membangun Masyarakat Memberdayakan Masyarakat. Rafika Aditama. Bandung.

Sukirno, Sadono, 2006, Makro ekonomi Modern" PT Raja Grafindo Persada, Jakarta

Tafsir.A.2004. Filsafat Ilmu. Remaja Rosdakarya. Bandung.

Taylor, B John, 2004. Economics. USA: Houghton Mifflin Company.

Todaro, Michael, 1986. Perencanaan Pembangunan Model dan Metode. Jakarta: Intermedia.

2004. Perencanaan Pembangunan Model dan Metode. Jakarta: Intermedia. 